\section{Ethylene, a Plant Hormone from Fluorescent Lighting}

FLUORESCENT lighting is used as a source of artificial light in plant growth chambers and to extend day length for plants grown in greenhouse conditions. The electrical circuit for a fluorescent light includes a ballast choke which usually consists of lacquered copper wire wound on an iron core and insulated with impregnated paper or cloth. We found that peas grown in our growth room were affected by ethylene which was being produced by the ballast chokes. Ethylene is a plant hormone which has a physiological effect on plants at concentrations as low as $0.06 \mu \mathrm{g} / \mathrm{l}$. (ref. 1).

Single ballast chokes (National $40 / 420$ and Ferguson $\mathrm{H1205}$ ) which were incubated in a sealed jar at $100^{\circ} \mathrm{C}$, the approximate external temperature during normal operation, gave off ethylene at the rate of $1.5 \mu \mathrm{g} / \mathrm{h}$. The gas mixtures were analysed by gas chromatography on an alumina column ${ }^{2}$. The ethylene may derive from breakdown of the lacquer insulation of the windings, because we found that lacquered copper wire held at $100^{\circ} \mathrm{C}$ also evolved ethylene.

Other hydrocarbons of low molecular weight given off by the ballasts were methane, ethane, propane, propene, 2-methylpropane, butane, but-1-ene, 2-methylpropene and pentane, but the amounts of these compounds were less than that of ethylene. From the data of Burg and Burg ${ }^{3}$, they would not be expected to affect plant growth.

CSIRO Division of Food Preservation,

R. B. H. WILLS

B. D. PatTerson*

PO Box 43, Ryde, NSW, Australia.

Received November 11, 1969.

* Alember of the Plant Physiology Unit.

1 Pratt, H. K., and Goeschl, J. D., Ann. Rev. Plant Physiol., 20, 541 (1969).

2 MeGlasson, W. B., Austral. J. Biol. Sci., 22, 489 (1969).

3 Burg, S. P., and Burg, E. A., Plant Physiol., 42, 144 (1967).

\section{“Airborne Organism" Identified}

IN a recent report ${ }^{1}$ R. D. Wiffen and M. J. Heard request identification of hollow particles, 0.5 micron in diameter, which were collected in an atmospheric aerosol at Harwell Atomic Energy Research Establishment. These appear to be solid excretory products known as brochosomes, produced by homopterous insects. These structures were first discovored adhering to the wings ${ }^{2}$ and were later shown to originate in the Malpighian tubules of the gut ${ }^{3}$, occurring in Golgi vesicles. A special behaviour pattern exists by which the hind legs distribute excrement over the wings ${ }^{5}$. One configuration is a twenty-sided polyhedron comprising eight hexagons and twelve pentagons ${ }^{4}$, which is identical to the much larger polyhedra of a radiolarian skeleton (Dorataspis cristata) ${ }^{6}$. Thompson noted $^{6}$ that such polyhedra can only exist if there is distortion in either edges or facets. These systems have obvious parallels with the quasi-cquivalently related protein subunits in icosahedral virus shells? The brochosomes consist of lipoprotein and may occur in various other configurations ${ }^{8}$.

ARC Unit of Insect Physiology,

\section{A. C. Nfinilie}

Department of Zoology, University of Oxford.

Received November 19, 1969.

1 Wiffen, R. D., and Heard, M. J., Nature, 224, 715 (1969).

${ }^{2}$ Tulloch, G. S., and Shapiro, J. E., Bull. Brooklyn Entomol. Soc., 48, 57 (1953).

${ }^{3}$ Day, M. F., and Briggs, M., J. Ultrastruct. Res., 2, 239 (1958).

S Smith, D. S., and Littau, V. O., J. Biophys. Biochem. Cytot., 8, 103 (1960).

${ }^{5}$ Storey, H. F., and Nichols, R. F. W., Proc. Roy. Ent. Soc. Lond., 12, 149 (1937).

- Thompson, D. W., On Growth and Form (second ed.) (Macmillan, New York, 1945)

'Caspar, D. L. D., and Klug, A., Cold Spring Harbor Symp. Quant. Biol., 27, 1 (1962).

sGouranton, J., and Mallet, P-L., J. Mieroscop., 8, 53 (1967).

\section{"Airborne Organism" Identified}

IF the authors of the recent report ${ }^{1}$ had chanced to include an insect physiologist among those consulted about the unusual objects detected by electron microscopy in an atmospheric aerosol, their quest would have been at an end! These structures are brochosomes, bizarre excretory products of the Malpighian tubules of leafhoppers (Homoptera; Jassidae). They were discovered on wing membranes and elsewhere on the surface of these insects by Tulloch, Shapiro and Cochrane ${ }^{2}$ and Wilde and Cochrane ${ }^{3}$, who named these structures to accord with their net-like form. Subsequently it was found 4 , by examination of thin sections in the electron microscope, that brochosomes are produced intracellularly in the urine-secreting tubules; their eventual distribution over the surface cuticle seems to be achieved by the insect manipulating the excreted pellets with its posterior pair of legs 5 .

Brochosomes are produced in agranular Golgi vesicles in cells of a restricted region in each Malpighian tubule, and released into the lumen across the apical cell surface. Histochemical tests suggest that these stable structures contain saturated lipid and protein, and lack RNA, polysaccharides, mucoproteins, uric acid and urates ${ }^{6}$. Reinvestigation of the formation and nature of brochosomes ${ }^{7}$ confirmed previous results but shed no further light on their significance or function.

A polyhedron with slightly curved surfaces on which there is an assortment of pentagonal and hexagonal sculpturing (resembling, in a 0.4 micron miniature, the siliceous skeleton of an acanthometrid radiolarian $)^{6,8}$ is not usual in the urine of most animals, and the fact that these structures are smeared in large numbers over the body surface of leafhoppers is fascinating but quite baffling. That they have been detected at Harwell ${ }^{1}$ reflects the efficiency of the sampling techniques, and the knowledge that brochosomes are present in the Berkshire air at a concentration of 1 per $5 \mathrm{l}$. indicates that use of insecticides in the area has not yet resulted in the extinction of leafhoppers.

David S. SMrTth

The Papanicolaou Cancer Research Institute and

School of Medicine,

University of Miami,

Miami, Florida.

Received Novcmber 25, 1969.

${ }^{1}$ Wiffen, R. D., and Heard, M. J., Nature, 224, 715 (1969).

'Tulloch, G. S., Shapiro, J. E., and Cochrane, G. W., Bull. Brooklyn Entomol, Soc.. 47, 41 (1952).

${ }^{3}$ Wilde, W. H. A., and Cochrane, G. W., Proc. Entomol. Soc. Brit. Columbia. 53, 19 (1957).

4 Day, M. F., and Briggs, M., J. Ultrastruct. Res., 2, 239 (1958).

${ }^{5}$ Storey, H. H., and Nichols, R. F. W., Proc. Roy. Ent. Soc. Lond., 12, 149 (1937).

'Smith, D. S., and Jittan, V. C., J. Biophys. Binchem. Cytol, , 8, 103 (1960).

${ }^{7}$ Gouranton, J., and Maillet, P-L., J. Microscop., 6, 53 (1967).

8 Thompson, D. W., On Giouth and Form (second ed.), 725 (Mracmillan, New York, 1945).

\section{"Newly" Recognized Mandible of Ramapithecus}

The recent report by David Pilbeam ${ }^{1}$ contains several categorical statements which seem to me to be unfounded, and others which are misleading.

Pilbeam's opening paragraph states: "A 'new' mandible from the Siwalik deposits... has been discovered in the fossil primate collection in the British Musoum (Natural History)". Then in the second paragraph, he adds that it "was recovered and donated to the Museum some years ago", and that "it has been unidentified until now".

The specimen is, in fact, part of a collection of fossils formerly belonging to the late H. M. Sale, and it was 